\title{
The dynamic links among energy consumption, tourism growth, and the ecological footprint: the role of environmental quality in 38 IEA countries
}

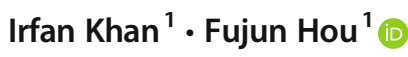 \\ Received: 15 July 2020 / Accepted: 14 September 2020 / Published online: 20 September 2020 \\ (C) Springer-Verlag GmbH Germany, part of Springer Nature 2020
}

\begin{abstract}
We examine the impact of energy consumption and tourism growth on the ecological footprints and economic growth of 38 International Energy Agency (IEA) countries, as moderated by labor and capital, over the 1995-2018 period. We develop a comprehensive empirical analysis that applies second-generation unit root and cross-section dependence analysis. The cointegration analysis indicates long-run relationships among the variables, while the fully modified least square (FMOLS) approach specifies that energy consumption promotes economic growth and degrades environmental quality in the long run, and tourism growth improves environmental quality and stimulates economic growth in the long run. In addition, the result of a pairwise Granger causality test reveals bidirectional causality between energy consumption and economic growth and unidirectional causality from the ecological footprint to energy consumption. Policy implications for theory and practice and directions for future research in the area are presented.
\end{abstract}

Keywords Ecological footprint $\cdot$ Environmental quality $\cdot$ Energy consumption $\cdot$ International tourism $\cdot$ Economic growth $\cdot 38$ IEA countries

\section{Introduction}

Since the beginning of this decade, growth has often been at the expense of sustainability. The ecological footprint (EFP) is an embryonic analytical tool in both environmental and tourism studies. Energy and tourism is an integral component of modern societies and key pillars of sustainable growth in the world. This paper applies the concept of the EFP to examining the impacts that energy consumption and tourism growth have on environmental quality. Rees and Wackernagel (1996) introduced the conception of the EFP, which measures the bio-productive surface required to sustain a population. The demand side of the EFP

Responsible Editor: Nicholas Apergis

Fujun Hou

houfj@bit.edu.cn

Irfan Khan

Khan.Irfan4032@yahoo.com; houfj@bit.edu.cn

1 School of Management and Economics, Beijing Institute of Technology, Beijing 100081, China deals with the ecological resources that a specific community needs to produce the natural assets it consumes and to absorbing waste, particularly carbon emissions (Bello et al. 2018; Kassouri and Altıntaș 2020; Long et al. 2020).

Energy consumption and tourism growth increase revenues, create employment, and contribute to a blueprint for achieving a sustainable future for all (Dogan and Aslan 2017; Gokmenoglu and Eren 2019; Işik et al. 2017; Zhang and Gao 2016). Per the Energy Information Agency (EIA), global energy consumption will grow from 549 quadrillion British thermal units (Btu) in 2012 to 815 quadrillion Btu in 2030, and the United Nations World Tourism Organization (UNWTO) predicts tourist arrivals to grow from 1 billion in 2012 to more than 1.8 billion in 2030 (Ișik et al. 2017). Such tourism and energy flows will bring multiple prospects, including cultural, social, job creations, and socio-economic development ${ }^{1}$.

These flows will bring with them increased EFPs and greenhouse gas emissions associated with both the tourism and energy sectors. Lenzen et al. (2018) found that the world's carbon emissions increased from 3.9 to $4.5 \mathrm{GtCO}_{2} \mathrm{e}$ between

\footnotetext{
${ }^{1}$ This estimate does not include consideration of COVID-19 epidemic.
} 
2009 and 2013 and that international tourism accounts for about $8 \%$ of the world's greenhouse gas emissions. Addressing the environmental degradation from the carbon emissions that are adversely associated with economic growth and sustainable efforts is required to preserve the environment (Azam 2016; Bah and Azam 2017; Liu et al. 2018; Ozcan and Ozturk 2019; Rafindadi and Ozturk 2017; Zaidi et al. 2019). The tourism sector accounts for $5 \%$ of the world's carbon dioxide $\left(\mathrm{CO}_{2}\right)$ emissions. The most conspicuous characteristic of both energy consumption and tourism is that they are linked through various networks; for example, international tourism is not only part of economic growth but is also linked to the pattern of energy consumption. Frantál and Urbánková (2017) argued that energy demand is closely associated with tourism activities, along with associated functions like accommodations, catering, transportations, and communications.

One facet of energy consumption is concerned with economic growth, while another is associated with carbon emissions (Waheed et al. 2019). Sustainable growth and preventing environmental change must be considered while fulfilling the growing energy demand. The energy supply from renewable sources can balance inconsistency in the energy-mix market and protect the ecological environment (Ogbonnaya et al. 2019). Renewable energy has become more important today because of its lean adverse effects on the environment compared to other energy resources (Razmi et al. 2020), so they constitute an essential part of the transformation to a low-carbon economy (Przychodzen and Przychodzen 2020). Moreover, energy consumption (nonrenewable and renewable) and international tourism flows can have positive impacts on foreign direct investment (FDI), research and development expenditures (R\&D), trade, employment, life quality, and the growth and development of a country (Amri 2019; Aslam and Awan 2018; Belaïd and Zrelli 2019a; Ben Jebli et al. 2019; Chen et al. 2019; Croes et al. 2018; Fan and Hao 2020; Isik et al. 2018; Kožić et al. 2019; Sokhanvar 2019a; $\mathrm{Wu}$ and $\mathrm{Wu}$ 2019; Yao et al. 2019; Zafar et al. 2019).

The primary objective of our research is to determine the impact of tourism growth and energy consumption on the EFPs and economic growth of 38 IEA countries and to identify the moderating effects of labor and capital. This study uses sustainable growth theory by highlighting the environmental sustainability and benefits of tourism development on the population's well-being and the environmental quality of 38 International Energy Agency (IEA) countries. The study contributes to research at the intersection of the environment, energy, and tourism growth.

This study addresses directly and indirectly several Sustainable Development Goals (SDGs), including SDG 7 regarding affordable and clean energy, SDG 8 regarding decent work and economic growth, SDG 12 regarding responsible production and consumption, and SDG 13 regarding climate actions, so it makes a significant contribution to the ongoing discussion in the literature on sustainability.
We employ principal component analysis (PCA) in constructing two indices. First, we form an index for energy consumption that merges the two primary sources of energy consumption: renewable energy consumption and non-renewable energy consumption. Second, we construct an index for important tourism indicators in which we merge 12 critical elements that relate to the tourism industry. Using these indices, we determine the impacts of energy consumption and tourism on the EFP and economic growth of IEA countries. Thus, the study is the first to use PCA to construct and estimate indices of these critical parts of sustainable growth theory.

The coordination of energy consumption and tourism growth with EFP has received relatively little attention in the literature, as has research at the intersection of the environment, energy, and tourism growth in IEA countries. No empirical research has been conducted on the probable connections among energy consumption, tourism growth, and the EFP for the IEA countries, so this study fills the vacuum by examining the prospective long-run relationship among the study variables for a balanced panel of 38 members and associations of the IEA family. Moreover, the literature is deficient in discussing the environmental impact of capital formation, and this study is the first to estimate the impact of capital formation on the EFP of IEA counties. In addition, we employ advanced econometric techniques, including cross-sectional dependence, second-generation stationary analysis, fully modified ordinary least square (FMOLS), and stacked conventional coefficient causality analysis, leading to empirical coverage that makes a significant contribution to the field.

The rest of the paper proceeds in the following manner: "Literature review" contains a literature review, while "Modeling and data" gives an overview of the modeling and data. "Methodological framework" demonstrates the methodological framework, and results are provided and discussed in "Results and discussion." "Policy implications" lists policy implications, and "Conclusion" provides concluding remarks.

\section{Literature review}

We review three primary aspects of the literature on the relationships of energy consumption, capital formation, and tourism growth with the EFP and economic growth: the intersection between energy consumption and economic growth-EFP nexus, the intersection among tourism growth; economic growth and the EFP; and the intersection among capital formation, economic growth, and the EFP.

\section{The intersection among energy consumption, economic growth, and the EFP}

According to the IEA (2018), world energy consumption in 2018 increased at about twice the average growth rate since 2010, 
resulting in increased environmental deterioration during that year, a record. Dogan et al. (2020) investigated the impact of renewable energy consumption on the economic growth of OECD countries from 1990 to 2010. Using panel quantile regression analysis, they explained the positive effects of renewable energy consumption on the economic growth of countries in the lower and middle-lower quantiles and adverse association with the middle, high middle, and high quantiles. Shahbaz et al. (2020) studied the effects of renewable energy consumption on the economic growth of 38 renewable energy-consuming countries from 1990 to 2018. Using FMOLS and DOLS regression approaches, they confirmed that renewable energy consumption is positively associated with the countries' economic growth. Balsalobre and Ali (2020) and Wang and Wang (2020) confirmed that the use of renewable energy is more effective in improving the economic growth of a country than the use of non-renewable energy. However, Apergis and Payne (2010) found an inverted $U$-shaped pattern of energy consumption and economic growth associated with the environmental Kuznets curve (EKC).

Wang et al. (2020) argued that biomass energy production stimulates EFP in G-7 countries, deteriorating environmental quality in the long run. Baz et al. (2020a, b) examined the asymmetric impact of energy consumption on Pakistan's EFP from 1971 to 2014 and found a negative relationship between energy consumption and environmental quality. Charfeddine (2017) explored the impact of energy consumption and economic development on Qatar's EFP and $\mathrm{CO}_{2}$ emissions over the period from 1970 to 2015 and found that EFP held a $U$-shape during the study period. However, using a quantile autoregressive distributed lag model (QARDL), Sharif et al. (2020a) confirmed a negative long-term equilibrium relationship between energy consumption and the EFP in Turkey.

Although the literature contains diverse findings, we expect energy consumption to be positively associated with EFP and economic growth in IEA countries.

\section{The intersection among tourism growth, economic growth, and the EFP}

Brida et al. (2020) empirically examined the relationship between tourism and economic growth for 80 countries over the period from 1995 to 2016 and concluded that tourism contributed positively to economic growth both directly and indirectly. Croes et al. (2021) used a limited information maximum likelihood (LIML) approach to investigate tourism specialization, economic growth, and transition economies for Poland, concluding that tourism specialization has a shortterm positive impact on economic growth. Croes et al. (2021) also incorporated an industry-level analysis of the relationship between tourism and economic growth in the USA from 1998 to 2017 and found that investment in tourism development may lead to long-run equilibrium economic growth even during economic stagnation, but tourism may not effectively stimulate economic growth in the short run, as it may take a cue from the general economy. Fahimi et al. (2018a, b) tested empirically the role of tourism in influencing the economic growth of micro states from 1995 to 2015 and found that the tourism sector did not contribute to economic growth over the study period.

Overall, the current literature is deficient in its discussion of the impact of tourism growth on EFP. However, studies like those of Croes et al. (2021), Hunter and Shaw (2007), and Lin et al. (2017) addressed various environmental aspects of tourism. Lin et al. (2017) checked the dynamics of tourists' EFP in Shanghai from 2008 to 2013 and demonstrated that tourists' traffic footprint and tourists' shopping footprint had a significant influence on environmental quality in Shanghai. Ramı and Martı (2010) analyzed the impact on the EFP of road transport related to tourism activities for Lanzarote Island and found that tourism activities can provide a global perspective on environmental impacts.

Based on this part of the review, we expect that tourism can have a favorable effect on environmental quality by encouraging ecological conservation and protection. Therefore, we suppose that tourism growth is positively associated with economic growth and is adversely associated with the EFPs of IEA countries.

\section{The intersection among capital formation, economic growth, and the EFP}

Capital formation is considered the backbone of any country's growth and development, but the recent literature has not extensively discussed these relationships. Using the ARDL and an error correction model (ECM), Bal et al. (2016) found a significant positive relationship between capital formation and economic growth in India from 1970 to 2012, while Udom et al. (2020) demonstrated a positive association between capital formation and economic growth in Malaysia from 1980 to 2014. The same positive relationship between capital formation and economic growth was the conclusion of the studies by Adebola and Shahbaz (2015) and Topcu et al. (2020).

The existing literature also lacks an empirical analysis of the environmental impacts of capital formation. Capital formation contributes about $30 \%$ of the global greenhouse gases (GHGs), so leaving it out is a significant oversight. No studies have explored the impact of capital formation on EFP; only that by Wood and Hertwich (2017) has disclosed that capital formation has considerable environmental influence, finding that capital formation constitutes $57 \%$ of the $\mathrm{CO}_{2}$ emissions in China. Worldwide, the construction sector causes $60 \%$ of China's EFP, and capital formation for infrastructure related to buildings and roads account for $83 \%$ of that.

Therefore, we contend that capital formation stimulates economic growth and increases the EFP, hence deteriorating environmental quality in IEA countries. 


\section{Modeling and data}

\section{Theoretical background}

We determined the theoretical framework of the study before diving into the econometric modeling so we can define the model's variables. The IEA economies are characterized by swift economic development, and this instantaneous growth is considerably on the hand of production, distribution, and higher energy consumption. The literature has employed the EFP as a measure for various objectives. We use the EFP as the determinant of environmental quality (Solarin et al. 2019). The associations of energy consumption and tourism growth with EFP and economic growth have been lightly examined in the literature, which has found that energy supply and prices have direct associations with tourism development. Energy for essential substructure, electrical, and the consumption of fuels for transportation, cooling, cooking, living, and many other facilities are prerequisites for tourism (He et al. 2020). Non-renewable energy is depends primarily on burning of fossil fuels, which breaks down hydrocarbons, creating air pollution. Therefore, this kind of energy consumption is not only a danger to the environment but also a challenge to sustainable development. With the current levels of environmental control and consumer demand, the tourism sector must become more environmentally feasible (Arrivals and Consumption 2019).

The tourism sector should endorse clean energy initiatives by providing energy-saving lodging, solar heating and cooling, and renewable technologies (He et al. 2020). Consumption of clean energy like solar, tidal, and wind power, and others are central to changing tourist behavior related to travel and energy and a way forward to sustainable tourism.

The energy-generation process requires extensive capital and investment, which relates to a country's economic growth, so the effects of energy consumption and tourism development on the EPT and economic growth can vary. Using alternative energy resources requires the engagement of economic indicators like labor, capital, and R \& D. Labor, capital formation, and energy are the physical production factors that produce industrial outputs (Henningsen et al. 2019; Vural 2020). From this viewpoint, energy consumption, tourism growth, labor, and capital may have diverse and significant impacts on the EFP and sustainable economic growth. Figure 1 illustrates the study's theoretical framework.

\section{Economic modeling}

We use PCA to construct two indices. First, we form an index for energy consumption, in which we merge the two primary sources of energy: renewable energy consumption and nonrenewable energy consumption. Second, we construct an index of tourism indicators in which we merge 12 critical elements of the tourism industry. Using these indices, we use labor and capital as the control variables in an examination of the influence of energy consumption and tourism growth on the EFPs and economic growth of IEA countries.

$$
\begin{aligned}
\text { Model-I } Y_{\mathrm{it}}= & \beta_{0}+\beta_{1} \text { ENERGY }_{\mathrm{it}}+\beta_{2} \text { TOURISM }_{\mathrm{it}} \\
& +\beta_{3} L_{\mathrm{it}}+\beta_{4} K_{\mathrm{it}}+\varepsilon_{\mathrm{it}} .
\end{aligned}
$$

Model-II EFP $_{\text {it }}=\beta_{0}+\beta_{1}$ ENERGY $_{\text {it }}+\beta_{2}$ TOURISM $_{\text {it }}$

$$
+\beta_{3} L_{\mathrm{it}}+\beta_{4} K_{\mathrm{it}}+\varepsilon_{\mathrm{it}} .
$$

We transform all the variables into their log forms to ensure the precision of the econometric analysis and elastic interpretations. $Y$ is gross domestic product (GDP), $t$ is the time (19952018), $i$ is the cross-section $(1,2,3, \ldots \mathrm{N}), L$ is the total labor force, $K$ is the gross fixed capital formation, $\beta_{0}$ is a constant, and $\beta_{1}$ to $\beta_{4}$ are the coefficients of energy consumption, tourism growth, labor, and capital, respectively.

\section{Data}

The central objective of our research is to determine the impact of tourism growth and energy consumption on the EFPs and economic growth of 38 IEA countries and to identify the moderating effects of labor and capital. The IEA comprises 38 countries, 30 of which are member countries, while the other 8 are association countries. (A list of the 38 IEA countries is shown in Appendix Table 8). We collected the balanced panel data from the IEA, the World Travel and Tourism Organization (WTTO), and the Global Footprint Network (GFN), and World Development Indicators (WDI) from the 1995 to 2018. Table 1 provides details about the variables we incorporated into this research.

\section{Methodological framework}

\section{Cross-section dependency assessment}

The panel data set exhibits considerable cross-sectional dependence in the random errors (De Hoyos and Sarafidis 2006). Phillips and Sul (2003) showed that cross-section dependence (CD) is the prime issue with balanced panel data, as most of the countries are linked with one another as part of the global village. This study employs Pesaran's (2004) CD test to keep the research coefficients from inconsistency, as shown in equation (3).

$\mathrm{CD}=\sqrt{\frac{2 T}{N(N-1)}}\left(\sum_{i=1}^{N-1} \sum_{j=i+1}^{N} \rho_{\mathrm{ij}}\right)$,

where $N$ is the sample size, $T$ is the period, and $\rho_{\mathrm{ij}}$ is the direct correlation error for each cross-section $i$ and $j$. Breusch 
Fig. 1 Theoretical framework

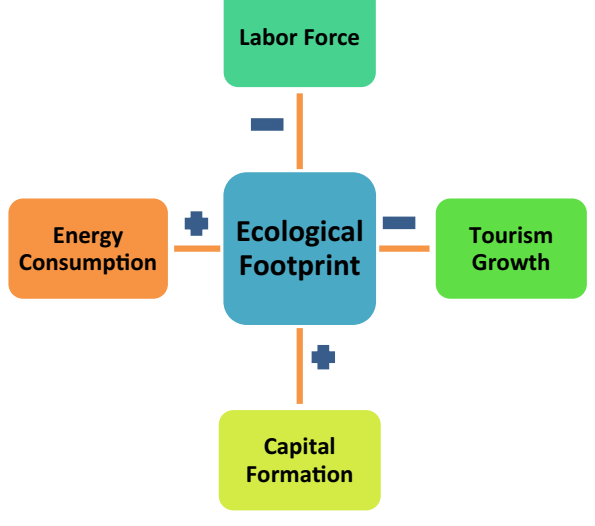

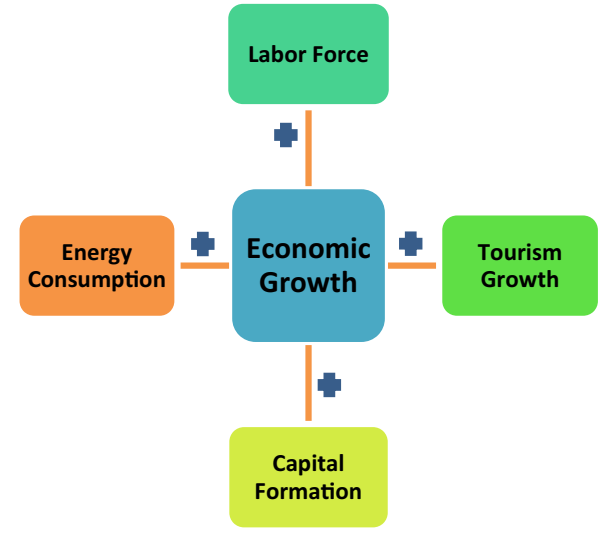

and Pagan (1980) proposed the Langrage multiplier (LM) estimate for $\mathrm{CD}$ and used the following equation:

$Y_{\text {it }}=a_{i}+B_{i} X_{\text {it }}+\varepsilon_{\text {it }}$,

where $i$ is the direction of each cross-section and $t$ is time. The null hypothesis supports the cross-section independence and an alternative to CD.

\section{Second-generation panel unit root test}

Dogan and Seker (2016) found that the first-generation unit root test is insufficient for checking the cross-section properties, so the purpose of the second-generation unit root test is to overcome this deficiency. This study uses the second-generation panel unit root test using augmented

Table 1 Description of variables

\begin{tabular}{|c|c|c|c|c|}
\hline Variable name & Symbols & Unit of measurement & Definition & Source \\
\hline GDP & $Y$ & Current US\$ & $\begin{array}{l}\text { Gross value added by all domestic manufacturers within the } \\
\text { boundary, including taxes and subtracting subsidies. }\end{array}$ & WDI \\
\hline Ecological footprint & EFP & Per capita gha & Ecological footprint of consumption of gha per capita & GFN \\
\hline Total labor force & $L$ & Total labor force & $\begin{array}{l}\text { Workers presently employed and currently unemployed but } \\
\text { seeking jobs. }\end{array}$ & WDI \\
\hline Gross fixed capital formation & $K$ & Current US\$ & $\begin{array}{l}\text { Land improvements, machinery, purchase of equipment, } \\
\text { industrial and commercial road construction, institutions, } \\
\text { buildings, etc. }\end{array}$ & WDI \\
\hline Renewable energy Consumption & Energy & Electricity output (GWh) & $\begin{array}{l}\text { Energy production from geothermal, solar, hydro, wind, } \\
\text { tide/wave/ocean energy, biofuels, and renewable waste } \\
\text { sources. }\end{array}$ & IEA \\
\hline Non-renewable energy consumption & & Electricity output (GWh) & $\begin{array}{l}\text { Energy production from peat, coal, oil, shale, natural gas, } \\
\text { and oil sources. }\end{array}$ & IEA \\
\hline Tourism capital investment & Tourism & US\$ in bn (real prices) & Capital investment in international tourism. & WTTC \\
\hline $\begin{array}{l}\text { Government tourism individual } \\
\text { expenditures }\end{array}$ & growth & US\$ in bn (real prices) & Government spending on international tourism services. & WTTC \\
\hline $\begin{array}{l}\text { Outbound travel and tourism } \\
\text { expenditure }\end{array}$ & & US\$ in bn (real prices) & Spending outside the country by residents on all visits abroad. & WTTC \\
\hline Visitor exports (foreign spending) & & US\$ in bn (real prices) & Expenditure within the host country by international travelers. & WTTC \\
\hline Leisure tourism spending & & US\$ in bn (real prices) & $\begin{array}{l}\text { Spending on leisure tourism in a county by citizens and } \\
\text { international visitors. }\end{array}$ & WTTC \\
\hline Tourism contribution to employment & & $\%$ of total employment & The number of jobs generated by the tourism sector. & WTTC \\
\hline Business tourism spending & & US\$ in bn (real prices) & $\begin{array}{l}\text { Spending on corporate tourism in a country by local and } \\
\text { global companies. }\end{array}$ & WTTC \\
\hline Tourism contribution to GDP & & US\$ in bn (real prices) & GDP produced by industries related to tourism. & WTTC \\
\hline $\begin{array}{l}\text { Internal travel and tourism } \\
\text { consumption }\end{array}$ & & US\$ in bn (real prices) & $\begin{array}{l}\text { Domestic spending by residents and individual government } \\
\text { expenses. }\end{array}$ & WTTC \\
\hline Domestic tourism spending & & US\$ in bn (real prices) & Host country residents' spending on leisure trips. & WTTC \\
\hline International arrivals & & Number of arrivals & $\begin{array}{l}\text { Inbound visitors or overnight visitors on the way to a } \\
\text { foreign nation. }\end{array}$ & WDI \\
\hline International tourism, receipts & & Current US\$ & $\begin{array}{l}\text { Spending by global inbound tourists during their visit to a } \\
\text { destination. }\end{array}$ & WDI \\
\hline
\end{tabular}


cross-section ISP (CIPS), and augmented cross-section ADF (CADF) approaches for stationary properties. Pesaran (2007) suggested using the CIPS CD in the unit root analysis:

$\Delta X_{\mathrm{it}}=\alpha_{\mathrm{it}}+\beta_{i} X_{\mathrm{it}-1}+\rho_{i} T+\sum_{j=1}^{n} \theta_{\mathrm{ij}} \Delta X_{i, t-j}+\varepsilon_{\mathrm{it}}$,

where $\Delta$ is the difference, $X_{\mathrm{it}}$ is the respective variable, $\alpha$ is an intercept, $T$ is the time for the balance panel, and $\varepsilon_{i t}$ is the error. Both the CIPS approach and the CADF approach confirm the null alternative hypothesis that each cross-section is non-stationary, and at least one cross-section in the balanced panel is stationary.

\section{Panel co-integration analysis}

Many panel co-integration techniques have been applied by researchers like Pedron's (Engle-Granger-based) technique and Fisher's (combined Johensen) technique. However, the advantage of the Kao test of co-integration is that it calculates and pools all the residuals of all the cross-sections in the panel data set and assumes that each co-integrating vector in each cross-section is identical (De Hoyos and Sarafidis 2006). This study employs a Kao's (1999) panel co-integration test to confirm the long-run associations among the study variables:

$$
\mathrm{DF}^{*}=\frac{t_{\rho}+\frac{\sqrt{6 N} \widehat{\sigma}_{v}}{2 \widehat{\sigma}_{0 v}}}{\sqrt{\frac{\widehat{\sigma}_{0 v}^{2}}{2 \widehat{\sigma}_{v}^{2}}+\frac{3 \widehat{\sigma}_{v}^{2}}{10 \widehat{\sigma}_{o v}^{2}}}},
$$

where $t_{\rho}$ is the parametric t-statistic, $\widehat{\sigma}_{v}^{2}$ and $\widehat{\sigma}_{0 v}^{2}$ are stable estimates of $\sigma_{v}^{2}$ and $\sigma_{0 v}^{2}, \widehat{\sigma}_{v}^{2}=\widehat{\sigma}_{v}^{2}-\widehat{\sigma}_{v \varepsilon}^{2} \sigma_{\varepsilon}^{-2}$ is the short-run variance estimate, and $\widehat{\sigma}_{\mathrm{ov}}^{2}=\widehat{\sigma}_{\mathrm{ov}}^{2}-\widehat{\sigma}_{\mathrm{ov} \varepsilon}^{2} \sigma_{0 \varepsilon}^{-2}$ is the long-run variance estimate.

\section{Panel fully modified ordinary least squares}

We employ a panel FMOLS approach to approximate the long-run coefficients. The regression model proposed by Pedroni (2000) is shown in equation (7):

$y_{\mathrm{it}}=\alpha_{i}+\beta x_{\mathrm{it}}+\mu_{\mathrm{it}}$,

where $x_{\mathrm{it}}=x_{\mathrm{it}-1}+\varepsilon_{\mathrm{it}}, i=1, \ldots, N$, and $t=1, \ldots, T$, for which we model the vector error process. The advantage of using the FMOLS approach over other long-run estimates is that it can overcome inference problems (Bashier 2014). We also apply an empirical distribution test, a pairwise correlation analysis, and stacked coefficients Granger causality tests to confirm the causal relationships among the variables.

\section{Results and discussion}

Table 2 presents the outcome of the pairwise correlation estimates and the newly developed empirical distribution tests that employ the Lilliefors, Cramer-von Mises, Watson, and Anderson-Darling methods for economic growth $(Y)$, EFP, energy consumption, tourism growth, labor force, and capital formation. The results reveal that all variables are significantly normally distributed at the $1 \%$ level of significance. Correlation analysis reveals a healthy interdependence among the variables.

We incorporate the test for CD using LM methodologies, as shown in Table 3 . The results from these approaches confirm the need to reject the null hypothesis at a $1 \%$ significance level. Hence, the balanced panel data of our study variables enjoys CD. The first-generation unit root test cannot fully capture the $\mathrm{CD}$ or heterogeneity errors among the panel data sets. Table 4 shows the outcome of the second-generation panel unit root test that considers the heterogeneity and $\mathrm{CD}$. The result reveals that economic growth, energy consumption, tourism growth, labor force, and capital formation possess unit root problems at the level, and so are non-stationary. However, the firstdifference transformation makes the variables stationary, so at the level, all variables of this study are non-stationary, whereas they are stationary at the first-order difference, which is of degree one I (1).

After performing the stationary analysis and checking the order of integration, we used Kao's residual test of cointegration to establish the long-run association among the research variables. Table 5 presents the outcome of panel co-integration, which firmly rejects the alternative hypothesis of no long-run relationships among the variables. Hence, our variables have long-run positive associations and move together in the long run.

We used the FMOLS model for the long-run estimates and approximations. Table 6 shows the outcomes of FMOLS models I and II, for which economic growth $(Y)$ and EFP (environmental quality) are the dependent variables, respectively. Energy consumption, tourism growth, labor force, and capital formation are the independent variables in both models. The results show that all variables are significant at the $1 \%$ level, as all the corresponding probability values are too small. In both models, energy consumption is positively associated with the economic growth and the EFPs of IEA countries, while tourism growth is positively related to economic growth in model I and adversely associated with the EFPs of IEA countries. 
Table 2 Empirical distribution and pairwise correlation tests

\begin{tabular}{|c|c|c|c|c|c|c|}
\hline Methods & $Y$ & EFP & Energy & Tourism & $L$ & $K$ \\
\hline Lilliefors (D) & $\begin{array}{l}0.035034^{* * * *} \\
(0.000)\end{array}$ & $\begin{array}{l}0.093102 * * * \\
(0.000)\end{array}$ & $\begin{array}{l}0.058140 * * * \\
(0.000)\end{array}$ & $\begin{array}{l}0.050894 * * * \\
(0.000)\end{array}$ & $\begin{array}{l}0.135439 * * * \\
(0.000)\end{array}$ & $\begin{array}{l}0.040212 * * * \\
(0.000)\end{array}$ \\
\hline Cramer-von Mises (W2) & $\begin{array}{l}0.220906^{* * *} \\
(0.000)\end{array}$ & $\begin{array}{l}1.532801 * * * \\
(0.000)\end{array}$ & $\begin{array}{l}0.559078^{* * *} \\
(0.000)\end{array}$ & $\begin{array}{l}0.684861 * * * \\
(0.000)\end{array}$ & $\begin{array}{l}1.727451^{* * *} \\
(0.000)\end{array}$ & $\begin{array}{l}0.287396^{* * * *} \\
(0.000)\end{array}$ \\
\hline Watson (U2) & $\begin{array}{l}0.216651^{* * * *} \\
(0.000)\end{array}$ & $\begin{array}{l}1.334251^{* * * *} \\
(0.000)\end{array}$ & $\begin{array}{l}0.559077 * * * \\
(0.000)\end{array}$ & $\begin{array}{l}0.672954 * * * \\
(0.000)\end{array}$ & $\begin{array}{l}1.665361 * * * \\
(0.000)\end{array}$ & $\begin{array}{l}0.271276 \text { *** } \\
(0.000)\end{array}$ \\
\hline Anderson-Darling (A2) & $\begin{array}{l}1.266232^{* * *} \\
(0.000)\end{array}$ & $\begin{array}{l}10.67387 * * * \\
(0.000)\end{array}$ & $\begin{array}{l}3.623910^{* * *} \\
(0.000)\end{array}$ & $\begin{array}{l}3.990858 * * * \\
(0.000)\end{array}$ & $\begin{array}{l}10.56941 * * * \\
(0.000)\end{array}$ & $\begin{array}{l}1.738145^{* * * *} \\
(0.000)\end{array}$ \\
\hline$Y$ & 1 & & & & & \\
\hline EFP & $\begin{array}{l}-0.0976^{* *} \\
(0.0032)\end{array}$ & 1 & & & & \\
\hline Energy & $\begin{array}{l}0.8724 * * * \\
(0.000)\end{array}$ & $\begin{array}{l}-0.3149 * * * \\
(0.000)\end{array}$ & 1 & & & \\
\hline Tourism & $\begin{array}{l}-0.0592 * \\
(0.0755)\end{array}$ & $\begin{array}{l}0.0672 * * \\
(0.0435)\end{array}$ & $\begin{array}{l}-0.0371 \\
(0.2658)\end{array}$ & 1 & & \\
\hline$L$ & $\begin{array}{l}0.7150 \text { *** } \\
(0.000)\end{array}$ & $\begin{array}{l}-0.6151 * * * \\
(0.000)\end{array}$ & $\begin{array}{l}0.8373 * * * \\
(0.000)\end{array}$ & $\begin{array}{l}-0.1299 * * * \\
(0.0001)\end{array}$ & 1 & \\
\hline$K$ & $\begin{array}{l}-0.1371 * * * \\
(0.000)\end{array}$ & $\begin{array}{l}0.0686^{* *} \\
(0.0384)\end{array}$ & $\begin{array}{l}-0.1180^{* * *} \\
(0.0004)\end{array}$ & $\begin{array}{l}0.9182^{* * * *} \\
(0.000)\end{array}$ & $\begin{array}{l}-0.2076^{* * *} \\
(0.000)\end{array}$ & 1 \\
\hline
\end{tabular}

***and**show significant at $1 \%$ and $5 \%$

Further, a $1 \%$ increase in energy consumption increases economic growth by $78 \%$ while degrading environmental quality by $47 \%$ in IEA economies. These findings are consistent with the studies of Alola et al. (2019), Baz et al. (2020a), and Sharif et al. (2020a). Further, a 1\% acceleration in tourism growth increases the economic growth of IEA countries by $34 \%$ in model I, while it decreases the EFP of IEA countries by $24 \%$ in model II. We found that both energy consumption and tourism growth are significant factors in the economic growth of IEA countries, a result that agrees with those of Adams et al. (2018), Aydin (2019), Belaïd and Zrelli (2019b), Mohamed et al. (2019), Rahman and Velayutham (2020), Troster et al. (2018), Vural (2020), and Zafar et al. (2019). All these studies showed that energy consumption is compatible with economic growth. Regarding tourism, our results are consistent with those of Antonakakis et al. (2015), Aratuo and Etienne (2019), Liu et al. (2019), Ohlan (2017), Saltik and Bahar (2019), and Tang and Tan (2015). All of these studies found that tourism growth encourages the economic growth process in a country. However, this study's results contrast the findings of Fahimi et al. (2018a, b), Sokhanvar (2019a, b), and Perles-Ribes et al. (2017), who found that the tourism sector does not contribute to economic growth.

Similarly, capital formation is positively associated with economic growth and the EFPs of IEA countries in the study period, as a $1 \%$ increase in capital formation increases economic growth by $40 \%$ and the EFP by $75 \%$. Thus, although capital formation is a significant driver of economic growth, it also harms the environmental quality of IEA countries. Capital formation includes land improvements, machinery, equipment purchases, industrial and commercial road construction, institutions, and buildings, and all these activities put pressure on the EFP, hence adversely impact environmental quality. However, the labor force positively contributes to economic growth while decreasing the EFPs of IEA countries, as a $1 \%$ increase in the labor force increases economic growth by $12 \%$ and reduce the EFP by $86 \%$. Thus, although an

Table 3 Cross-section dependency sssessments

\begin{tabular}{lllllll}
\hline Variables & $Y$ & EFP & Energy & Tourism & $L$ & $K$ \\
\hline CD test & $117.8978^{* * * *}$ & 21.56462 & $69.35476^{* * *}$ & $104.9532 * * *$ & $92.86507 * * *$ & $98.35242^{* * *}$ \\
$P$ value & 0.000 & 0.000 & 0.000 & 0.000 & 0.000 & 0.000 \\
LM test & $357.2002 * * *$ & 109.3641 & $228.5541 * * *$ & $295.8590 * * *$ & $289.0432 * * *$ \\
$P$ value & 0.000 & 0.000 & 0.000 & 0.000 & 0.000 \\
\hline
\end{tabular}

$* * *$ show significant at $1 \%$ 
Table 4 Panel unit root assessments

\begin{tabular}{lllll}
\hline Variables & $\begin{array}{l}\text { CIPS } \\
\text { Level }\end{array}$ & $\begin{array}{l}\text { First- } \\
\text { difference }\end{array}$ & $\begin{array}{l}\text { CADF } \\
\text { Level }\end{array}$ & $\begin{array}{l}\text { First- } \\
\text { difference }\end{array}$ \\
\hline$Y$ & 4.27669 & $-12.9990^{* * * *}$ & 4.51202 & $-12.5151^{* * *}$ \\
EFP & 0.20820 & $-27.1306 * * *$ & 0.58282 & $-21.3578 * * *$ \\
Energy & 4.28801 & $-20.7928 * * *$ & 4.44087 & $-17.4986 * * *$ \\
Tourism & 0.97518 & $-19.6284 * * *$ & 1.07010 & $-17.0478^{* * *}$ \\
$L$ & 1.96327 & $-12.6175^{* * *}$ & 2.22672 & $-11.4171^{* * *}$ \\
$K$ & 0.72806 & $-12.8534 * * *$ & 1.10268 & $-12.3629 * * *$ \\
\hline
\end{tabular}

$* * *$ show significant at $1 \%$

increase in the labor force does not contribute much to economic growth, it has a significant effect on environmental quality and sustainability. Figure 2 provides a Kernel density scatterplot matrix, which explains the multiple interactions among the study variables.

Table 6 provides the long-run estimates, while Table 7 shows the result of the commonly stacked coefficients causality analysis, which analyzed the causal relationships among the variables. The analysis shows the presents of a bidirectional Granger relationship among energy consumption, the labor force, and GDP. However, a one-way Granger relationship prevails from GDP, capital formation, and the EFP to energy consumption in the economies of the 38 IEA countries during the study period. Figure 3 presents all of these directional casual relationships among the variables. The result that energy consumption bidirectionally Granger causes economic growth is consistent with Sharif et al. (2020a, b). Our finding that energy consumption unidirectionally Granger causes EFP is contrary to the findings of Nathaniel (2020), who demonstrated no Granger relationship between energy use and EFP. Moreover, the result of no causality between tourism growth and economic growth is consistent with findings of Balli et al. (2018) and contrary to Ben Jebli et al. (2019), who found a unidirectional causality relationship between tourism and economic growth.

Table 5 Kao residual co-integration assessments

\begin{tabular}{|c|c|c|c|c|}
\hline \multirow[t]{2}{*}{ Methods } & \multicolumn{2}{|c|}{$\begin{array}{l}\text { Model I } \\
Y=\text { energy, tourism, } \\
L, K\end{array}$} & \multicolumn{2}{|c|}{$\begin{array}{l}\text { Model II } \\
\text { EFP = energy, } \\
\text { tourism, } L, K\end{array}$} \\
\hline & $t$ statistic & Probability & $t$ statistic & Probability \\
\hline $\mathrm{ADF}$ & $-3.013940 * * *$ & 0.0013 & $1.553986^{*}$ & 0.0601 \\
\hline $\begin{array}{l}\text { Residual } \\
\text { variance }\end{array}$ & $0.010349 * *$ & & 0.168034 & \\
\hline HAC variance & $0.012765 * *$ & & $0.087602 *$ & \\
\hline
\end{tabular}

$* * *, * *$ and $*$ show significant at $1 \%, 5 \%$, and $10 \%$

\section{Policy implications}

The underlying relationships and the long-run elasticities between the study variables explore the satirical navigational associations among the variables, and understanding these relationships is crucial for efficient and environmentally friendly energy design and tourism policies.

Overall, the statistical estimations of this research suggest that energy consumption and tourism encourage the economic growth process. However, energy consumption promotes EFPs, while tourism activities lower them. Likewise, there is a directional causal relationship between EFP and tourism growth, energy consumption, and economic growth. Table 6 reveals that, although a $1 \%$ increase in energy consumption increases the EFP by $47 \%$, energy consumption's contribution to economic growth is much higher (78\%). Therefore, we suggest that the governments of IEA countries increase energy consumption to increase economic growth but emphasize the uses of renewable energy to protect the environmental quality (Schober et al. 2018; Zafar et al. 2019). Energy consumption from renewable sources plays an active role in reducing energy poverty and dependence on foreign-produced energy while ensuring energy efficacy. IEA nations should motivate and develop strategies that will give opportunities for investors to invest in the production and consumption of renewable energy. Furthermore, the governments of IEA countries should work toward meeting clean production thresholds by pushing capital formation toward renewable energy sources. The governments of all IEA countries, especially Austria, Belgium, Canada, the Czech Republic, Denmark, Estonia, Slovak, Morocco, and a few others, should reduce their subsidies of non-renewables in favor of investing in renewable energy. At the initial phase of transformation from one kind of energy to the other, a considerable amount of investment is required for the technological upgrade to the process of developing renewable energy. These shifts from non-renewable to renewable energy sources create multiple externalities for these economies.

Based on our findings, we suggest that decision-makers implement such policies that will improve the critical relationship between tourism, economic growth, and the EFP. Table 6 shows that a $1 \%$ increase in tourism growth increases economic growth by $34 \%$ and reduces the EFP by 24\%. These figures are significant but could improve with the introduction of coordinated and comprehensive tourism policies and practices. Based on the findings shown in Table 6, we suggest that IEA economies foster landmark tourism brands by integrating tourism with local cultural and natural resources and by increasing spending on capital investments related to tourism, business tourism, and domestic and leisure tourism spending. These steps will strengthen the tourism industry, which may prove to be a 
Table 6 Panel fully modified ordinary least squares analysis

\begin{tabular}{|c|c|c|c|c|c|c|}
\hline \multirow[t]{2}{*}{ Variable } & \multicolumn{3}{|c|}{$\begin{array}{l}\text { Model I } \\
Y=\text { energy, tourism, } L, K\end{array}$} & \multicolumn{3}{|c|}{$\begin{array}{l}\text { Model II } \\
\mathrm{EFP}=\text { energy, tourism, } L, K\end{array}$} \\
\hline & Coefficient & $t$ statistic & Probability & Coefficient & $t$ statistic & Probability \\
\hline Energy & $0.782423 * * *$ & 33.68940 & 0.0000 & $0.467133 * * *$ & 4.087449 & 0.0000 \\
\hline Tourism & $0.342580 * * *$ & 2.792948 & 0.0054 & $-0.237497 * * *$ & -5.805714 & 0.0000 \\
\hline$L$ & $1.236651 * * *$ & 14.24619 & 0.0000 & $-0.861702 * * *$ & -12.55037 & 0.0000 \\
\hline K & $0.401930 * * *$ & 22.38260 & 0.0000 & $0.754691 * * *$ & 17.04050 & 0.0000 \\
\hline
\end{tabular}

**** show significant at $1 \%$

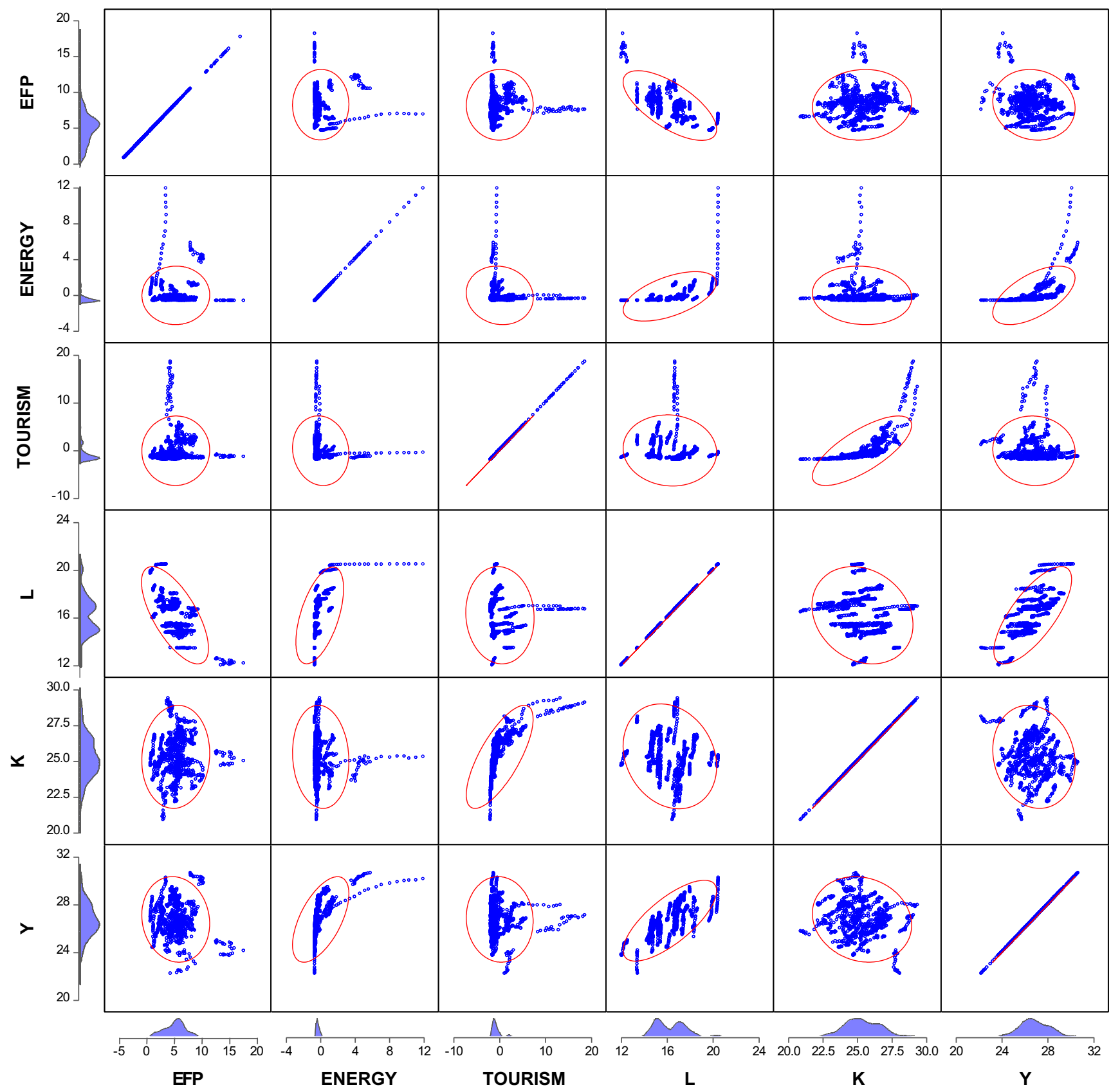

Fig. 2 Kernel density scatterplot matrix 
Table 7 Stacked common coefficients causality analysis

\begin{tabular}{|c|c|c|c|c|c|}
\hline \multirow{2}{*}{$\begin{array}{l}\text { Model I } \\
Y=\text { energy, tourism, } L, K \\
\text { Null hypothesis }\end{array}$} & \multirow[b]{2}{*}{$F$ statistic } & \multirow[b]{2}{*}{ Probability } & \multirow{2}{*}{$\begin{array}{l}\text { Model II } \\
\text { EFP = energy, tourism, } L, K \\
\text { Null hypothesis }\end{array}$} & \multirow[b]{2}{*}{$F$ statistic } & \multirow[b]{2}{*}{ Probability } \\
\hline & & & & & \\
\hline Energy does not Granger causes $Y$ & 7.37371 & $0.0007 * * *$ & Energy does not Granger causes EFP & 0.61590 & 0.5404 \\
\hline$Y$ does not Granger causes energy & 4.30576 & $0.0138 * *$ & EFP does not Granger causes energy & 9.51753 & $0.0000 * * *$ \\
\hline Tourism does not Granger causes $Y$ & 1.10185 & 0.3327 & Tourism does not Granger causes EFP & 0.13586 & 0.8730 \\
\hline$Y$ does not Granger causes tourism & 1.48596 & 0.2269 & EFP does not Granger causes tourism & 0.84377 & 0.4305 \\
\hline$L$ does not Granger causes $Y$ & 8.34158 & $0.0003^{* * *}$ & $L$ does not Granger causes EFP & 1.48296 & 0.2276 \\
\hline$Y$ does not Granger causes $L$ & 5.33707 & $0.0050 * *$ & EFP does not Granger causes L & 2.02330 & 0.1329 \\
\hline$K$ does not Granger causes $Y$ & 0.15280 & 0.8583 & $K$ does not Granger causes EFP & 0.63328 & 0.5311 \\
\hline$Y$ does not Granger causes $K$ & 4.28284 & $0.0141 * *$ & EFP does not Granger causes K & 0.01739 & 0.9828 \\
\hline
\end{tabular}

***and ${ }^{* *}$ show significant at the $1 \%$ and $5 \%$

powerful instrument for sustainable community growth, and that can reduce the prevailing income inequalities. The tourism sector can be an active player in the developing IEA nations' ability to contribute to the world economy. By adopting these measures, these economies can make humans and cities safer, more resilient, and more sustainable. Tourism growth can help to ensure sustainable production and consumption patterns and contest the impacts of climate change (Coles et al. 2015; Danish,, and Wang, Z. 2018; Fitchett et al. 2017; Gössling and Peeters 2015; $\mathrm{Yu}$ et al. 2019).

Our study provides a way to address directly and indirectly several SDGs, including SDG 7, SDG 8, and SDG 13. Investment in the renewable energy and tourism sectors may create employment opportunities, lending support to SDG 8 and SDG 12. Hence, sustained economic growth may be possible while implementing the thresholds of various SDGs.

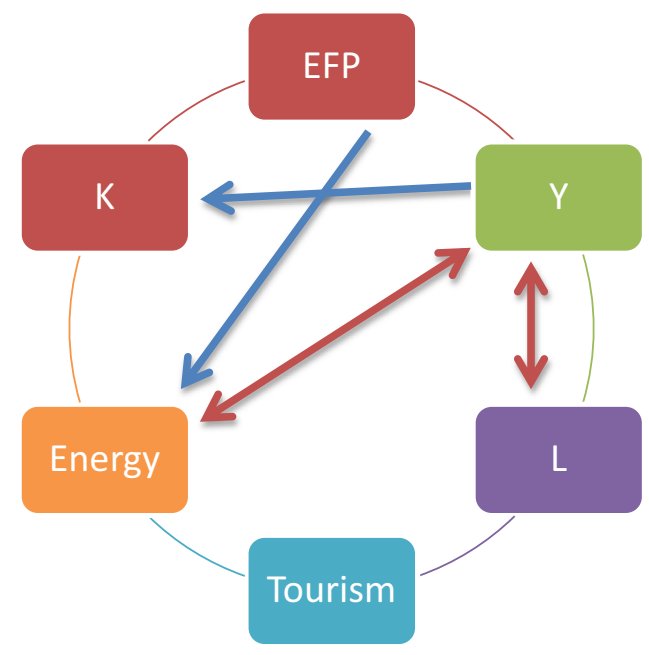

Bidirectional

Unidirectional

Fig. 3 Stacked common coefficients causality analysis

\section{Conclusion}

Energy is the lifeline of an economy. This paper supports sustainable growth theory by highlighting the benefits of energy consumption and tourism for environmental sustainability and economic growth in IEA countries. We use PCA to construct two indices, one for energy consumption, in which we merge renewable and non-renewable energy consumption, and one for important tourism indicators, where we combine 12 critical symbols of the tourism industry. Using these indices, we explore the impact of energy and tourism on the EFP and the economic growth of IEA countries in two multivariate production functions using labor and capital as the control variables. We collect the balanced panel data from IEA, WTTO, GFN, and WDI from1995 to 2018 and convert all the variables into their log forms to ensure the precision of the econometric analysis and elastic interpretations.

We perform the descriptive statistical analysis using an empirical distribution test and pairwise correlation analysis, apply advanced econometric techniques for the empirical analysis, and use the $\mathrm{CD}$ test and second-generation unit root tests for stationary analysis. We use the Kao residual test of co-integration to determine the long-run association among the variables, the FMOLS approach to obtain the long-run coefficient approximations, and pairwise Granger causality analysis to identify causal relationships.

The CD and LM methodologies reject the null hypothesis and confirm that our panel data set has CD. The unit root test from the CIPS and CADF methodologies confirm that the study's variables have unit roots at the level but not at firstdifferences that are I (1). The outcome of the Kao residual test of co-integration shows that the study's variables have a longrun positive association with each other for the 38 IEA member and association countries. Hence, all these variables support and move together in the long run. Pairwise Granger causality runs among the significant policy variables. The outcome of FMOLS reveals that energy consumption positively 
associated with the economic growth and EFPs of IEA countries, while tourism growth is positively related to economic growth and adversely associated with the EFPs of the IEA countries.

This study plays an essential part in establishing the literature at the intersection of EFP, energy, tourism, and sustainable growth. Tourism, energy consumption, EFP, and economic growth are profoundly interconnected and affect one another, so economic policymakers in IEA countries should encourage sustainable, environmentally feasible tourism strategies to effect sustainable economic growth. Likewise, the think tanks of these economies should consider tourism strategies that support sustainable economic growth through the use of reusable energy.

This paper has a limitation in its decision not to divide the 38 IEA countries into the association and member countries or into developing and developed countries. Future research could consider these perspectives in their analysis. Future research could also divide the countries in terms of income to check the effects differently. This research incorporates and stresses the environmental perspectives using the EFP, but future research could also include the socio-economic and political aspects of IEA countries.

Authors' contributions Irfan Khan: writing - original draft preparation, conceptualization, methodology, modeling, and software etc. Dr. Fujun Hou: supervision and reviewing.

\section{Compliance with ethical standards}

Competing interests The authors declare that they have no competing interests.

\section{Appendix}

Table 8 List of IEA countries

\begin{tabular}{llll}
\hline $\begin{array}{l}\text { Association } \\
\text { countries }\end{array}$ & $\begin{array}{l}\text { Member } \\
\text { countries }\end{array}$ & & \\
\hline Brazil & Australia & Germany & Norway \\
China & Austria & Hungry & Poland \\
India & Belgium & Ireland & Portugal \\
Indonesia & China & Italy & Slovak Republic \\
Morocco & Canada & Japan & Spain \\
Singapore & Czech Republic & Korea & Sweden \\
South Africa & Denmark & Luxembourg & Switzerland \\
Thailand & Estonia & Mexico & Turkey \\
& Finland & New Zealand & United Kingdom \\
& France & Netherlands & United States \\
\hline
\end{tabular}

\section{References}

Adams S, Klobodu EKM, Apio A (2018) Renewable and non-renewable energy, regime type and economic growth. Renew Energy 125:755767. https://doi.org/10.1016/j.renene.2018.02.135

Adebola S, Shahbaz M (2015) Natural gas consumption and economic growth: the role of foreign direct investment, capital formation and trade openness in Malaysia. Renew Sust Energ Rev 42:835-845

Alola AA, Bekun FV, Sarkodie SA (2019) Dynamic impact of trade policy, economic growth, fertility rate, renewable and nonrenewable energy consumption on ecological footprint in Europe. Sci Total Environ 685:702-709. https://doi.org/10.1016/j.scitotenv. 2019.05.139

Amri F (2019) Renewable and non-renewable categories of energy consumption and trade: do the development degree and the industrialization degree matter? Energy 173:374-383. https://doi.org/10.1016/ j.energy.2019.02.114

Antonakakis N, Dragouni M, Filis G (2015) How strong is the linkage between tourism and economic growth in Europe? Econ Model 44: 142-155. https://doi.org/10.1016/j.econmod.2014.10.018

Apergis N, Payne JE (2010) The emissions, energy consumption, and growth nexus: evidence from the commonwealth of independent states. Energy Policy 38(1):650-655. https://doi.org/10.1016/j. enpol.2009.08.029

Aratuo DN, Etienne XL (2019) Industry level analysis of tourismeconomic growth in the United States. Tour Manag 70(9):333340. https://doi.org/10.1016/j.tourman.2018.09.004

Arrivals T, Consumption E (2019) Centre for applied macroeconomic analysis tourist arrivals, energy consumption and pollutant emissions in a developing economy - implications for sustainable tourism.

Aslam M, Awan PDAG (2018) Impact of monetary policy on economic growth: evidence from Pakistan. Global Journal of Management, Social Sciences and Humanities 4(1):89-109 Retrieved from www.gjmsweb.com.editor@gjmsweb.com, https://www.academia. edu/35721375/IMPACT OF MONETARY POLICY ON ECONOMIC GROWTH EVIDENCE FROM PAKISTAN.

Aydin M (2019) Renewable and non-renewable electricity consumptioneconomic growth nexus: evidence from OECD countries. Renew Energy 136:599-606. https://doi.org/10.1016/j.renene.2019.01.008

Azam M (2016) Does environmental degradation shackle economic growth? A panel data investigation on 11 Asian countries. Renew Sust Energ Rev 65:175-182. https://doi.org/10.1016/j.rser.2016.06. 087

Bah MM, Azam M (2017) Investigating the relationship between electricity consumption and economic growth: evidence from South Africa. Renew Sust Energ Rev 80:531-537. https://doi.org/10. 1016/j.rser.2017.05.251

Bal DP, Dash DP, Subhasish B (2016) The Effects of Capital Formation on Economic Growth in India: Evidence from ARDL-bound Testing Approach. Glob Bus Rev 17(6):1-13. https://doi.org/10. 1177/0972150916660403

Balli E, Sigeze C, Manga M, Birdir S, Birdir K (2018) The relationship between tourism, $\mathrm{CO}_{2}$ emissions and economic growth : a case of Mediterranean countries. 1665. https://doi.org/10.1080/10941665. 2018.1557717

Balsalobre D, Ali M (2020) European commitment to COP21 and the role of energy consumption, FDI, trade and economic complexity in sustaining economic growth. J Environ Manag 273(8):111146. https://doi.org/10.1016/j.jenvman.2020.111146

Bashier A (2014) Immigration and economic growth in Jordan: FMOLS approach. Int J Hum Soc Sci Educ 1(9):85-92

Baz K, Xu D, Ali H, Ali I, Khan I, Khan MM, Cheng J (2020a) Asymmetric impact of energy consumption and economic growth on ecological footprint: using asymmetric and nonlinear approach. 
Sci Total Environ 718:137364. https://doi.org/10.1016/j.scitotenv. 2020.137364

Baz K, Xu D, Ali H, Ali I, Khan I, Muddassar M, Cheng J (2020b) Asymmetric impact of energy consumption and economic growth on ecological footprint: Using asymmetric and nonlinear approach. Sci Total Environ 718:137364. https://doi.org/10.1016/j.scitotenv. 2020.137364

Belaïd F, Zrelli MH (2019a) Renewable and non-renewable electricity consumption, environmental degradation and economic development: evidence from Mediterranean countries. Energy Policy 133(1):110929. https://doi.org/10.1016/j.enpol.2019.110929

Belaïd F, Zrelli MH (2019b) Renewable and non-renewable electricity consumption, environmental degradation and economic development: evidence from Mediterranean countries. Energy Policy 133(8):110929. https://doi.org/10.1016/j.enpol.2019.110929

Bello MO, Solarin SA, Yen YY (2018) The impact of electricity consumption on $\mathrm{CO}_{2}$ emission, carbon footprint, water footprint and ecological footprint: the role of hydropower in an emerging economy. J Environ Manag 219:218-230. https://doi.org/10.1016/j. jenvman.2018.04.101

Ben Jebli M, Ben Youssef S, Apergis N (2019) The dynamic linkage between renewable energy, tourism, $\mathrm{CO}_{2}$ emissions, economic growth, foreign direct investment, and trade. Latin Am Econ Rev 28(1). https://doi.org/10.1186/s40503-019-0063-7

Breusch TS, Pagan AR (1980) The Lagrange multiplier test and its applications to model specification in econometrics. Rev Econ Stud 47(1):239. https://doi.org/10.2307/2297111

Brida JG, Gomez DM, Segarra V (2020) On the empirical relationship between tourism and economic growth. Tour Manag 81:81(4). https://doi.org/10.1016/j.tourman.2020.104131

Charfeddine L (2017) The impact of energy consumption and economic development on ecological footprint and $\mathrm{CO}_{2}$ emissions: evidence from a Markov switching equilibrium correction model. Energy Econ 65:355-374. https://doi.org/10.1016/j.eneco.2017.05.009

Chen Y, Wang Z, Zhong Z (2019) CO2 emissions, economic growth, renewable and non-renewable energy production and foreign trade in China. Renew Energy 131:208-216. https://doi.org/10.1016/j. renene.2018.07.047

Coles T, Dinan C, Warren N (2015) Climate change mitigation and the age of tourism accommodation buildings: a UK perspective. J Sustain Tour 23(6):900-921. https://doi.org/10.1080/09669582. 2015.1027213

Croes R, Ridderstaat J, van Niekerk M (2018) Connecting quality of life, tourism specialization, and economic growth in small island destinations: the case of Malta. Tour Manag 65:212-223. https://doi.org/ 10.1016/j.tourman.2017.10.010

Croes R, Ridderstaat J, Monika B, Zientara P (2021) Tourism specialization, economic growth, human development and transition economies: The case of Poland. Tour Manag 82:104181. https://doi.org/ 10.1016/j.tourman.2020.104181

Danish, \& Wang, Z. (2018) Dynamic relationship between tourism, economic growth, and environmental quality. J Sustain Tour 26(11): 1928-1943. https://doi.org/10.1080/09669582.2018.1526293

De Hoyos RE, Sarafidis V (2006) Testing for cross-sectional dependence in panel-data models. Stata J 4:482-496

Dogan E, Aslan A (2017) Exploring the relationship among $\mathrm{CO}_{2}$ emissions, real GDP, energy consumption and tourism in the EU and candidate countries: evidence from panel models robust to heterogeneity and cross-sectional dependence. Renew Sust Energ Rev 77(4):239-245. https://doi.org/10.1016/j.rser.2017.03.111

Dogan E, Seker F (2016) Determinants of CO2 emissions in the European Union: the role of renewable and non-renewable energy. Renew Energy 94(2016):429-439. https://doi.org/10.1016/j.renene.2016. 03.078

Dogan E, Altinoz B, Madaleno M, Taskin D (2020) The impact of renewable energy consumption to economic growth: a replication and extension of. Energy Econ 90:104866. https://doi.org/10.1016/j. eneco.2020.104866

Fahimi A, Akadiri SS, Seraj M, Akadiri AC (2018a) Testing the role of tourism and human capital development in economic growth. A panel causality study of micro states. Tour Manag Perspect 28(4): 62-70. https://doi.org/10.1016/j.tmp.2018.08.004

Fahimi A, Akadiri SS, Seraj M, Akadiri AC (2018b) Testing the role of tourism and human capital development in economic growth. a panel causality study of micro states 2$\}$. Tour Manag Perspect 28(7):6270. https://doi.org/10.1016/j.tmp.2018.08.004

Fan W, Hao Y (2020) An empirical research on the relationship amongst renewable energy consumption, economic growth and foreign direct investment in China. Renew Energy 146:598-609. https://doi.org/ 10.1016/j.renene.2019.06.170

Fitchett JM, Robinson D, Hoogendoorn G (2017) Climate suitability for tourism in South Africa. J Sustain Tour 25(6):851-867. https://doi. org/10.1080/09669582.2016.1251933

Frantál B, Urbánková R (2017) Energy tourism: an emerging field of study. Curr Issue Tour 20(13):1395-1412. https://doi.org/10.1080/ 13683500.2014 .987734

Gokmenoglu KK, Eren BM (2019) The role of international tourism on energy consumption: empirical evidence from Turkey. Curr Issue Tour 23(9):1-7. https://doi.org/10.1080/13683500.2019.1574723

Gössling S, Peeters P (2015) Assessing tourism's global environmental impact 1900-2050. J Sustain Tour 23(5):639-659. https://doi.org/ 10.1080/09669582.2015.1008500

He L, Zha J, Loo HA (2020) How to improve tourism energy efficiency to achieve sustainable tourism: evidence from China. Curr Issue Tour 23(1):1-16. https://doi.org/10.1080/13683500.2018.1564737

Henningsen A, Henningsen G, van der Werf E (2019) Capital-labourenergy substitution in a nested CES framework: a replication and update of Kemfert (1998). Energy Econ 82:16-25. https://doi.org/ 10.1016/j.eneco.2017.12.019

Hunter C, Shaw J (2007) The ecological footprint as a key indicator of sustainable tourism. Tour Manag 28:46-57. https://doi.org/10.1016/ j.tourman.2005.07.016

IEA (2018) Global energy and $\mathrm{CO}_{2}$ status report: the least trends in energy and emissions in 2018, International Energy Agency, www.iea.org. 1-29. https://webstore.iea.org/download/direct/ 2461?fileName=Global_Energy_and_CO2_Status_Report_2018. pdf

Ișik C, Do gan E, Ongan S (2017) Analyzing the tourism-energy-growth nexus for the top 10 most-visited countries. Economies 5(4). https:// doi.org/10.3390/economies5040040

Isik C, Dogru T, Turk ES (2018) A nexus of linear and non-linear relationships between tourism demand, renewable energy consumption, and economic growth: theory and evidence. Int J Tour Res 20(1): 38-49. https://doi.org/10.1002/jtr.2151

Kao C (1999) Spurious regression and residual-based tests for cointegration in panel data. J Econ 90(1):1-44. https://doi.org/10. 1016/S0304-4076(98)00023-2

Kassouri Y, Altıntas H (2020) Human well-being versus ecological footprint in MENA countries: a trade-off? J Environ Manag 263(10): 110405. https://doi.org/10.1016/j.jenvman.2020.110405

Kožić I, Sorić P, Sever I (2019) Interdependence of international tourism demand for Mediterranean countries: impact of demand shocks. Int J Tour Res 21(1):97-107. https://doi.org/10.1002/jtr.2244

Lenzen M, Sun YY, Faturay F, Ting YP, Geschke A, Malik A (2018) The carbon footprint of global tourism. Nat Clim Chang 8(6):522-528. https://doi.org/10.1038/s41558-018-0141-x

Lin W, Li Y, Li X, Xu D (2017) The dynamic analysis and evaluation on tourist ecological footprint of city: take Shanghai as an instance authors. Sustain Cities Soc. https://doi.org/10.1016/j.scs.2017.12. 003

Liu D, Ruan L, Liu J, Huan H, Zhang G, Feng Y, Li Y (2018) Electricity consumption and economic growth nexus in Beijing: a causal 
analysis of quarterly sectoral data. Renew Sust Energ Rev 82(9): 2498-2503. https://doi.org/10.1016/j.rser.2017.09.016

Liu J, Cheng H, Jiang D, Huang L (2019) Impact of climate-related changes to the timing of autumn foliage colouration on tourism in Japan. Tour Manag 70(9):262-272. https://doi.org/10.1016/j. tourman.2018.08.021

Long X, Yu H, Sun M, Wang XC, Klemeš JJ, Xie W, Wang C, Li W, Wang Y (2020) Sustainability evaluation based on the threedimensional ecological footprint and human development index: a case study on the four island regions in China. J Environ Manag 265(4):110509. https://doi.org/10.1016/j.jenvman.2020.110509

Mohamed H, Ben Jebli M, Ben Youssef S (2019) Renewable and fossil energy, terrorism, economic growth, and trade: evidence from France. Renew Energy 139:459-467. https://doi.org/10.1016/j. renene.2019.02.096

Nathaniel SP (2020) Ecological footprint, energy use, trade, and urbanization linkage in Indonesia. GeoJournal 7. https://doi.org/10.1007/ s10708-020-10175-7

Ogbonnaya C, Abeykoon C, Damo UM, Turan A (2019) The current and emerging renewable energy technologies for power generation in Nigeria: a review. Thermal Science and Engineering Progress 13(6):100390. https://doi.org/10.1016/j.tsep.2019.100390

Ohlan R (2017) The relationship between tourism, financial development and economic growth in India. Future Bus J 3(1):9-22. https://doi. org/10.1016/j.fbj.2017.01.003

Ozcan B, Ozturk I (2019) Renewable energy consumption-economic growth nexus in emerging countries: a bootstrap panel causality test. Renew Sust Energ Rev 104(8):30-37. https://doi.org/10.1016/j.rser. 2019.01.020

Pedroni P (2000) Fully modified OLS for heterogeneous cointegrated panels. In: Advances in Econometrics, vol 15. https://doi.org/10. 1016/S0731-9053(00)15004-2

Perles-Ribes JF, Ramón-Rodríguez AB, Rubia A, Moreno-Izquierdo L (2017) Is the tourism-led growth hypothesis valid after the global economic and financial crisis? The case of Spain 1957-2014. Tour Manag 61:96-109. https://doi.org/10.1016/j.tourman.2017.01.003

Pesaran MH (2004) General Diagnostic Tests for Cross Section Dependence in Panels. Iza, (1240, (August)), 1-42. Retrieved from http://www.dspace.cam.ac.uk/handle/1810/446

Pesaran MH (2007) J Appl Econ 21(22):1-21. https://doi.org/10.1002/jae

Phillips PCB, Sul D (2003) Dynamic panel estimation and homogeneity testing under cross section dependence. Econ J 6(1):217-259. https://doi.org/10.1111/1368-423x.00108

Przychodzen W, Przychodzen J (2020) Determinants of renewable energy production in transition economies: a panel data approach. Energy 191(15):116583. https://doi.org/10.1016/j.energy.2019. 116583

Rafindadi AA, Ozturk I (2017) Impacts of renewable energy consumption on the German economic growth: evidence from combined cointegration test. Renew Sust Energ Rev 75(1):1130-1141. https://doi.org/10.1016/j.rser.2016.11.093

Rahman MM, Velayutham E (2020) Renewable and non-renewable energy consumption-economic growth nexus: new evidence from South Asia. Renew Energy 147:399-408. https://doi.org/10.1016/j. renene.2019.09.007

Ramı PP, Martı RR (2010) Ecological footprint analysis of road transport related to tourism activity: the case for Lanzarote Island. 31, 98-103. https://doi.org/10.1016/j.tourman.2009.01.007

Razmi SF, Ramezanian Bajgiran B, Behname M, Salari TE, Razmi SMJ (2020) The relationship of renewable energy consumption to stock market development and economic growth in Iran. Renew Energy 145:2019-2024. https://doi.org/10.1016/j.renene.2019.06.166

Rees W, Wackernagel M (1996) Urban ecological footprints: why cities cannot be sustainable - and why they are a key to sustainability introduction: transforming human ecology. Environ Impact Assess Rev:537-555. https://doi.org/10.1007/978-0-387-73412-5
Saltik A, Bahar O (2019) Panel cointegration analysis of relationship between international trade and tourism : case of Turkey and silk road countries 31(6), 361-369. https://doi.org/10.1016/j.tmp.2019. 07.003

Schober A, Šimunović N, Darabant A, Stern T (2018) Identifying sustainable forest management research narratives: a text mining approach. J Sustain For 37(6):537-554. https://doi.org/10.1080/ 10549811.2018.1437451

Shahbaz M, Raghutla C, Chittedi KR, Jiao Z, Vo XV (2020) The effect of renewable energy consumption on economic growth: evidence from the renewable energy country attractive index. Energy 118162: 118162. https://doi.org/10.1016/j.energy.2020.118162

Sharif A, Baris-tuzemen O, Uzuner G, Ozturk I, Sinha A (2020a) Revisiting the role of renewable and non-renewable energy consumption on Turkey's ecological footprint: Evidence from Quantile ARDL approach. Sustain Cities Soc 57(8):102138. https://doi.org/10.1016/j.scs.2020.102138

Sharif A, Baris-Tuzemen O, Uzuner G, Ozturk I, Sinha A (2020b) Revisiting the role of renewable and non-renewable energy consumption on Turkey's ecological footprint: evidence from Quantile ARDL approach. Sustain Cities Soc 57:102138. https:// doi.org/10.1016/j.scs.2020.102138

Sokhanvar A (2019a) Does foreign direct investment accelerate tourism and economic growth within Europe? Tour Manag Perspect 29(4): 86-96. https://doi.org/10.1016/j.tmp.2018.10.005

Sokhanvar A (2019b) Does foreign direct investment accelerate tourism and economic growth within Europe? Tour Manag Perspect 29(4): 86-96. https://doi.org/10.1016/j.tmp.2018.10.005

Solarin SA, Tiwari AK, Bello MO (2019) A multi-country convergence analysis of ecological footprint and its components. Sustain Cities Soc 46(1):101422. https://doi.org/10.1016/j.scs.2019.101422

Tang CF, Tan EC (2015) Does tourism effectively stimulate Malaysia's economic growth? Tour Manag 46(2015):158-163. https://doi.org/ 10.1016/j.tourman.2014.06.020

Topcu E, Altinoz B, Aslan A (2020) Global evidence from the link between economic growth, natural resources, energy consumption, and gross capital formation. Resources Policy 66(1):101622. https://doi.org/10.1016/j.resourpol.2020.101622

Troster V, Shahbaz M, Uddin GS (2018) Renewable energy, oil prices, and economic activity: a Granger-causality in quantiles analysis. Energy Econ 70:440-452. https://doi.org/10.1016/j.eneco.2018.01. 029

Udom M, Adebola S, Yorucu V, Victor F, Asumadu S (2020) Modeling natural gas consumption, capital formation, globalization, $\mathrm{CO} 2$ emissions and economic growth nexus in Malaysia: Fresh evidence from combined cointegration and causality analysis. Energy Strategy Reviews 31:100526. https://doi.org/10.1016/j.esr.2020. 100526

Vural G (2020) Renewable and non-renewable energy-growth nexus: a panel data application for the selected Sub-Saharan African countries. Resources Policy 65(10):101568. https://doi.org/10.1016/j. resourpol.2019.101568

Waheed R, Sarwar S, Wei C (2019) The survey of economic growth, energy consumption and carbon emission. Energy Rep 5:11031115. https://doi.org/10.1016/j.egyr.2019.07.006

Wang Q, Wang L (2020) Effect of renewable energy consumption on economic. Energy 118200:118200. https://doi.org/10.1016/j. energy.2020.118200

Wang Z, Bui Q, Zhang B, Le T, Pham H (2020) Biomass energy production and its impacts on the ecological footprint: an investigation of the G7 countries. Sci Total Environ 140741:140741. https://doi.org/ 10.1016/j.scitotenv.2020.140741

Wood R, Hertwich EG (2017) Environmental impacts of capital. J OfIndustrial Ecol 22(1):1-13. https://doi.org/10.1111/jiec.12532 
Wu TP, Wu HC (2019) Tourism and economic growth in Asia: a bootstrap multivariate panel Granger causality. Int J Tour Res 21(1):8796. https://doi.org/10.1002/jtr.2243

Yao S, Zhang S, Zhang X (2019) Renewable energy, carbon emission and economic growth: a revised environmental Kuznets curve perspective. J Clean Prod 235:1338-1352. https://doi.org/10.1016/j. jclepro.2019.07.069

Yu L, Bai Y, Liu J (2019) The dynamics of tourism's carbon footprint in Beijing, China. J Sustain Tour 27(10):1553-1571. https://doi.org/ 10.1080/09669582.2019.1648480

Zafar MW, Shahbaz M, Hou F, Sinha A (2019) From nonrenewable to renewable energy and its impact on economic growth: the role of research \& development expenditures in Asia-Pacific Economic Cooperation countries. J Clean Prod 212:1166-1178. https://doi. org/10.1016/j.jclepro.2018.12.081
Zaidi SAH, Wasif M, Shahbaz M, Hou F (2019) Dynamic linkages between globalization, financial development and carbon emissions: Evidence from Asia Pacific Economic Cooperation countries. J Clean Prod 228:533-543. https://doi.org/10.1016/j.jclepro.2019. 04.210

Zhang L, Gao J (2016) Exploring the effects of international tourism on China's economic growth, energy consumption and environmental pollution: evidence from a regional panel analysis. Renew Sust Energ Rev 53:225-234. https://doi.org/10.1016/j.rser.2015.08.040

Publisher's note Springer Nature remains neutral with regard to jurisdictional claims in published maps and institutional affiliations. 